\title{
УДК 614.8
}

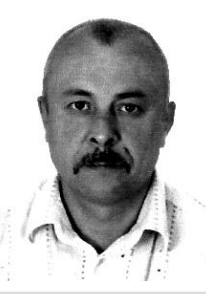

Г. В. Іванець

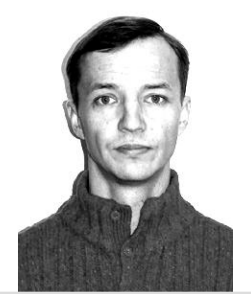

С. А. Горєлишев

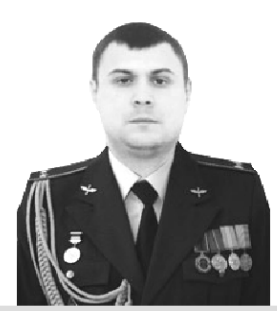

М. Г. Іванець

\section{СТАТИСТИЧНИЙ МЕТОД ОЦІНЮВАННЯ ЗАГРОЗ ТЕРИТОРІЯМ ТА НАСЕЛЕННЮ АДМІНІСТРАТИВНО-ТЕРИТОРІАЛЬНИХ ОДИНИЦЬ ДЕРЖАВИ}

У статті на основі середньостатистичної щзорічної кількості надзвичайних ситуацій розроблено статистичний метод оцінювання стану загроз територіям та населенню адміністративнотериторіальних одиниць держави з урахуванням їх площі та чисельності населення. Метод дозволяє класифікувати адміністративно-територіальні одиниці (регіони) держави за відповідними рівнями стану загроз територї̈ та населенню регіону: відносно оптимальний, відносно припустимий та відносно неприйнятний.

Клю ч ч о в $i$ с л о в а: надзвичайна ситуаиія, адміністративно-територіальна одиниия, комплексний показник, рівні стану загроз.

Постановка проблеми. Останнім часом у всьому світі спостерігається стійка тенденція збільшення протиріч між людиною та оточуючим природним середовищем. Все це призводить до виникнення надзвичайних ситуацій $(\mathrm{HC})$ i їх складових за видами, рівнями і регіональним розподілом, наслідки яких негативно впливають на економіку країн $[1,2]$. Наприклад, тільки за останні п'ять років в Україні виникло 795 НС, внаслідок яких загинуло 1266 та постраждало 5213 людей, завдано матеріальних збитків державі на 1599 млн грн [3-5].

Попередження надзвичайних ситуацій - це сукупність заходів законотворчого, економічного, адміністративного, технічного та іншого характеру, спрямованих на виявлення та вивчення причин виникнення НC, прогнозування їх розвитку, розробку і реалізацію заходів, які забезпечують їх усунення або нейтралізацію $[6,7]$.

Особливого значення щодо попередження та реагування на НС набуває інформація, яка містить відомості про прогнозовані й такі, що вже виникли, НС природного й техногенного характеру та їх наслідки, а також відомості про потенційні можливості підрозділів цивільного захисту держави 3 ліквідації можливих наслідків НС [8].

Захист населення та території від НС є однією з найважливіших задач цивільного захисту держави. Забезпечення безпеки у НС потребує надійного функціонування системи реагування на НС природного, техногенного та соціального характеру, адекватної рівням і характеру загроз [9]. Важливим аспектом цієї діяльності є завчасне оцінювання та прогнозування стану загроз територіям та населенню регіонів країни, оскільки сили цивільного захисту розподілені на території держави в межах адміністративно-територіальних одиниць (областей, районів, міст тощо). Кожній адміністративно-територіальній одиниці (AТрО) властиві свої рівні природних, техногенних та соціальних ризиків, що суттєво впливає на склад сил і засобів для адекватного реагування на НС природного, техногенного та соціального характеру.

Аналіз останніх досліджень і публікацій. Існують окремі підходи до кількісного оцінювання рівня загроз техногенного та природного характеру територіям і населенню регіонів держави.

Так, у праці [10] розроблені показники оцінювання стану загроз території та зроблена спроба іiі розподілу за декількома рівнями загроз окремо для НС техногенного та природного характеру.

Розглянуті у праці [11] методи оцінювання рівня небезпеки життєдіяльності в умовах прояву НС не враховують причини виникнення факторів небезпеки та особливості прояву нелінійних взаємозв'язків між ними.

(C) Г. В. Іванець, С. А. Горєлишев, М. Г. Іванець, 2019 


\section{Г. В. Іванець, С. А. Горелищев, М. Г. Іванець. Статистичний метод оцінювання загроз територіям та населенню адміністративно-територіальних одиниць держсави}

У статті [12] наведені спроби побудови і використання інтегральних показників оцінки та аналізу рівня безпеки життєдіяльності потенційно небезпечних об'єктів території за умов базового кількісного розподілу, що розкривають причинно-наслідкові зв'язки управління людськими, матеріальними, інформаційними ресурсами для забезпечення досягнення цілей проекту регіонального розвитку.

Наданий у праці [13] аналіз методів оцінювання рівня небезпеки життєдіяльності в умовах прояву НC не враховує причини виникнення факторів небезпеки та особливості прояву нелінійних взаємозв'язків між ними.

У сататтях $[14,15]$ як комплексний показник небезпеки території держави в умовах прояву НС природного та техногенного характеру взято вектор середньої за період моніторингу інтенсивності суми НС техногенного та природного характерів у $i$-й області країни, але в такому випадку не враховується інтенсивність НС соціального характеру і, головне, - площа території АТрО та чисельність населення, яке проживає на ній.

Таким чином, існуючі методи оцінювання рівня загроз життєдіяльності в умовах прояву НС не повною мірою враховують причини виникнення факторів небезпеки та існування взаємозв'язків між ними, що призводять до розвитку НС, які негативно впливають на умови нормального функціонування регіонів держави. Крім того, слід врахувати, що рівні загроз внаслідок НС в АТрО держави 3 різною площею території і кількістю проживаючого населення будуть мати зовсім інший характер та суттєво відрізнятися один від одного навіть за однакової інтенсивності НС.

Мета та задачі дослідження. Метою статті є розроблення статистичного методу оцінювання стану загроз територіям та населенню АТрО держави з урахуванням їх площ та чисельності населення. Для досягнення поставленої мети необхідно вирішити такі задачі:

- вибрати показник оцінювання стану загроз територіям та населенню АТрО держави;

- розробити метод та модель оцінювання стану загроз територям та населенню АТрО держави;

- провести експериментальні дослідження можливості застосування даного методу.

Виклад основного матеріалу. Для формування комплексного показника оцінювання стану загроз територіям та населенню АТрО держави будемо виходити з того, що ступінь небезпеки кожного регіону визначається середньостатистичною щорічною кількістю НС, а наслідки від них залежать як від кількості НС, так і від площі території та чисельності населення, яке проживає на ній [16].

Комплексний показник, що характеризує стан загроз територіям та населенню АТрО держави 3 урахуванням чисельності населення та площ їх територій визначається таким чином:

$$
Z_{i}=\Pi_{\text {насел. }}^{\mathrm{ATpO}} \cdot \bar{n}_{i \mathrm{ATpO}},
$$

де $\Pi_{\text {насел. }}^{\mathrm{ATpO}}=\frac{N_{\text {насел }}^{\mathrm{ATpO}}}{S_{\text {терит }}^{\text {ATO }}}-$ питома вага населення $i$-ї АТрО держави на одиницю площі її території; $N_{\text {насел }}^{\mathrm{ATpO}}-$ загальна кількість населення $i$-ї АТрО держави; $S_{\text {терит }}^{\mathrm{ATpO}}$ - загальна площа території $i$-ї AТрО держави; ${\overline{n_{i}}}_{\text {АТрО }}$ - середньостатистична щорічна кількість НС в $i$-й АТрО держави.

Узагальнений комплексний показник, що характеризує стан загроз території та населення на одну АТрО держави, має вигляд

$$
Z_{\text {держ }}=\Pi_{\text {насел }}^{\text {держ}} \cdot \bar{n}_{\text {держ }},
$$


де $\Pi_{\text {насел }}^{\text {деж }}=\frac{N_{\text {насел }}^{\text {держ }}}{S_{\text {терит }}^{\text {держ }}}-$ питома вага населення держави на одиницю площі іï території; $N_{\text {насел }}^{\text {держ }}-$ загальна кількість населення держави; $S_{\text {терит }}^{\text {деж }}$ загальна площа території держави; $\bar{n}_{\text {держ }}-$ середньостатистична щорічна кількість НС на одну АТрО держави.

Нормування $Z_{i}$ відносно $Z_{\text {держ }}$ дозволяє ввести коефіцієнт щорічної інтенсивності НС АТрО держави

$$
k_{z_{i}}=\frac{Z_{i}}{Z_{\text {держ }}} .
$$

Порівняльне оцінювання стану загроз територіям та населенню АТрО держави здійснюється шляхом зіставлення $Z_{i}$ та $Z_{\text {держ }}$.

Рівень стану загроз територіям та населенню АТрО держави вважається відносно оптимальним, якщо відповідні значення $Z_{i}$ більше ніж на третину нижче за значення $Z_{\text {держ }}$ у країні.

Рівень стану загроз територіям та населенню АТрО держави вважається відносно припустимим, якщо відповідні значення $Z_{i}$ відрізняються від значення $Z_{\text {держ }}$ не більше ніж на третину.

Рівень стану загроз територіям та населенню АТрО держави вважається відносно неприйнятним, якщо відповідні значення $Z_{i}$ перевищують значення $Z_{\text {держ }}$ в країні більше ніж на третину.

3 урахуванням цього критерії визначення меж рівнів стану загроз територіям та населенню АТрО держави будуть такі:

- відносно оптимальний рівень загроз територіям та населенню АТрО держави

$$
k_{z_{i}}<\frac{2}{3}
$$

- відносно припустимий рівень загроз територіям та населенню АТрО держави:

$$
\frac{2}{3} \leq k_{z_{i}} \leq \frac{4}{3}
$$

- неприйнятний рівень загроз територіям та населенню АТрО держави

$$
k_{z_{i}}>\frac{4}{3}
$$

На основі запропонованого методу розроблена модель оцінювання стану загроз територіям та населенню регіонів держави. Структура моделі наведена на рисунку. Вона включає об'єднані в єдине ціле логічно та інформаційно зв'язані між собою за призначенням, вирішуємими задачами, вхідними і вихідними даними модулі. 


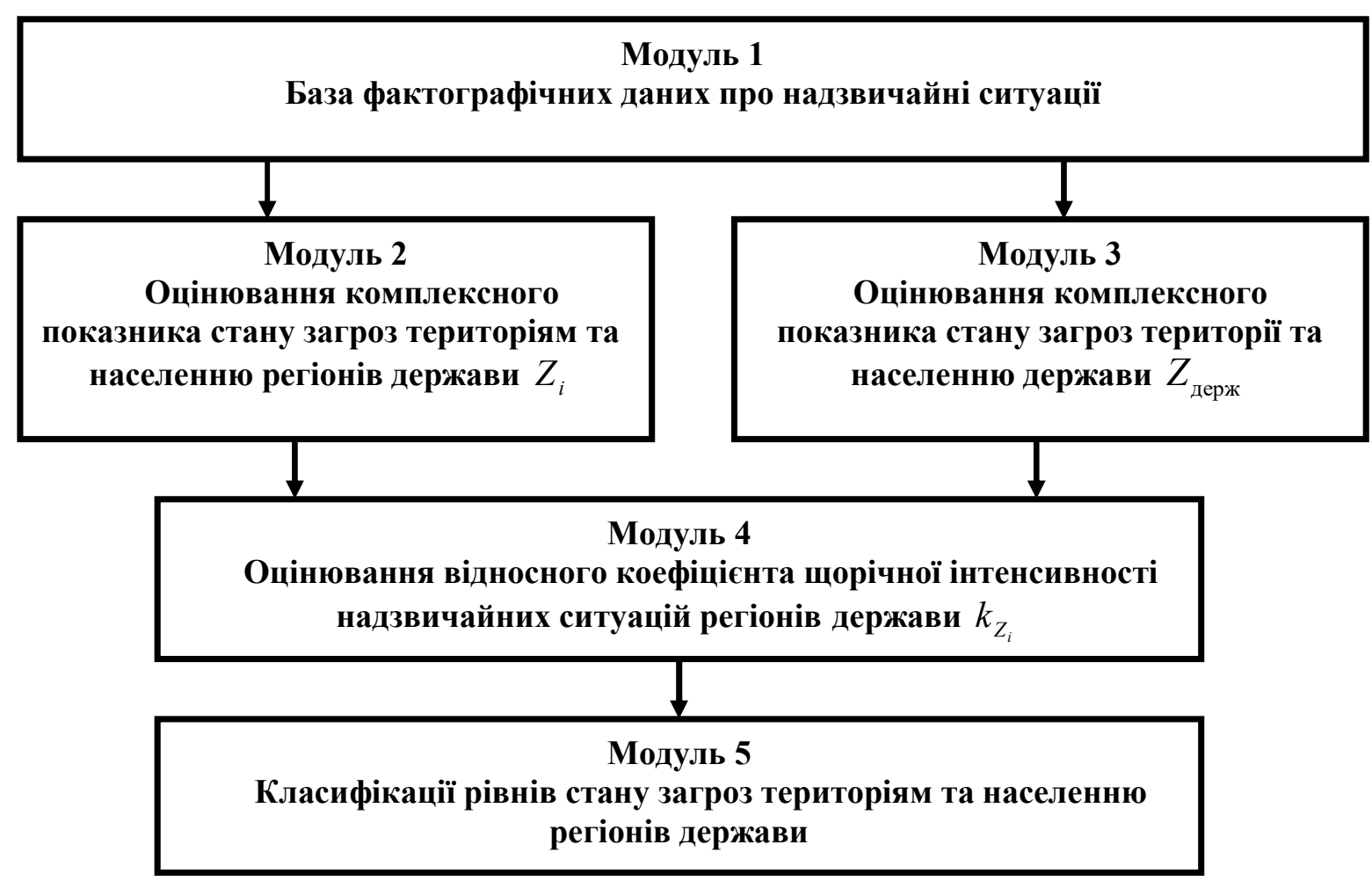

Модель оцінювання стану загроз територіям та населенню регіонів держави

Модуль 1 є базою фактографічних даних про НС природного, техногенного та соціального характеру як у державі в цілому, так і в іiі регіонах. Ці дані містять узагальнену фактографічну інформацію про НС за деякий період моніторингу.

Модуль 2 призначений для оцінювання комплексного показника стану загроз територіям та населенню регіонів держави $Z_{i}$ відповідно до виразу (1). Дані для проведення розрахунків надходять від модуля 1.

Модуль 3 призначений для оцінювання комплексного показника стану загроз території та населенню на одну АТрО держави $Z_{\text {держ }}$ відповідно до виразу (2). Дані для проведення розрахунків надходять від модуля 1.

Модуль 4 призначений для оцінювання відносного коефіцієнта щорічної інтенсивності НС регіонів держави $k_{z_{i}}$ відповідно до виразу (3). Дані для проведення розрахунків надходять від модулів 2 та 3.

Модуль 5 призначений для класифікації рівнів стану загроз територіям та населенню регіонів держави відповідно до виразів (4) - (6) на основі даних, які надходять від модуля 4.

Згідно з моделлю на основі фактографічної інформації проведені розрахунки щодо класифікації за рівнями стану загроз територіям та населенню регіонів України. Вхідну емпіричну основу дослідження складають фактографічні дані, наведені в офіційних виданнях про стан техногенної та природної безпеки в Україні [3] щодо кількості НС техногенного, природного та соціального характеру по областях України. Результати досліджень наведені в таблиці. 
Класифікаиія за рівнями стану загроз територіям регіонів України

\begin{tabular}{|l|l|}
\hline \multicolumn{1}{|c|}{$\begin{array}{c}\text { Рівень стану загроз територіям та } \\
\text { населенню регіонів }\end{array}$} & \multicolumn{1}{|c|}{ Регіони } \\
\hline Відносно оптимальний & $\begin{array}{l}\text { Волинська, Житомирська, Кіровоградська, } \\
\text { Полтавська, Рівненська, Сумська, Тернопільська, } \\
\text { Херсонська, Хмельницька, Черкаська, Чернігівська } \\
\text { області }\end{array}$ \\
\hline Відносно припустимий & $\begin{array}{l}\text { Вінницька, Закарпатська, Запорізька, Івано- } \\
\text { Франківська, Київська, Одеська, Чернівецька, } \\
\text { Харківська області }\end{array}$ \\
\hline Неприйнятний & $\begin{array}{l}\text { АРК, Донецька, Луганська, Дніпропетровська, } \\
\text { Львівська області }\end{array}$ \\
\hline
\end{tabular}

Таким чином, в результаті досліджень встановлено, що неприйнятний рівень загроз території та населенню характерний для АРК, Донецької, Луганської, Дніпропетровської та Львівської областей. Це свідчить про низьку ефективність заходів з попередження НС у цих регіонах країни.

\section{Висновки}

1. Обгрунтовано комплексний показник оцінювання стану загроз територіям та населенню АТрО держави, який враховує не тільки середньостатистичну щорічну кількість НС, а й площі територій та чисельність населення, яке проживає на них.

2. Розроблено статистичний метод та модель оцінювання стану загроз територіям та населенню ATpO держави із урахуванням площі їх території та чисельності населення, які дозволяють класифікувати регіони держави за відповідними рівнями стану загроз: відносно оптимальний, відносно припустимий та відносно неприйнятний.

3. У результаті експериментальних досліджень на основі статистичних даних про НС в Україні встановлено, що неприйнятний рівень загроз території та населенню характерний для АРК, Донецької, Луганської, Дніпропетровської та Львівської областей. Це свідчить про низьку ефективність заходів з попередження НС у цих регіонах.

\section{Перелік джерел посилання}

1. Guskova N. D., Neretina E. A. Threats of natural character, factors affecting sustainable development of territories and their prevention. Journal of the Geographical Institute Jovan Cvijic, SASA. 2013. Vol.63, Issue 3. P. 227-237. doi:https://doi.org/10.2298/iigil.303227g.

2. Development of combined method for predicting the process of the occurrence of emergencies of natural character / Ivanets H. et al. Eastern-European Journal of Enterprise Technologies. 2018. Vol. 5, Issue 10(95). P. 48-55. doi:https://doi.org/10.15587/1729-4061.2018.143045.

3. Звіт про основні результати діяльності Державної служби України з надзвичайних ситуацій у 2017 році. URL: http://www.dsns.gov.ua/ files/2018/1/26/Zvit\%202017(KMУ). pdf (дата звернення: 08.08.2018).

4. Іванець Г. В. Аналіз стану техногенної, природної та соціальної небезпеки адміністративнотериторіальних одиниць України на основі даних моніторингу. Збірник наукових праць Харківського університету Повітряних Сил. Харків: ХУПС, 2016. Вип. 3 (48). С. 142-145.

5. Numerical simulation of the creation of a fire fighting barrier using an explosion of a combustible charge / D. Dubinin et al. Eastern-European Journal of Enterprise Technologies. 2017. 6(10 (90)). P. 11-16. doi: 10.15587/1729-4061.2017.114504.

6. Nivolianitou Z., Synodinou B. A. Towards emergency management of natural disasters and critical accidents: The Greek experience. Journal of Environmental Management, 2011. Vol. 92, Issue 10. P. 26572665. doi:https://doi.org/10.1016/j.jenvman.2011.06.003.

7. Голован Ю. В., Козырь Т. В. Защита населения в чрезвычайных ситуациях. Организационные основы. Учебно-методический комплекс. Владивосток: Дальневосточный федеральный ун-т, 2016. 220 с. 


\title{
Г. В. Іванець, С. А. Горєлищев, М. Г. Іванець. Статистичний метод оцінювання загроз територіям та населенню адміністративно-територіальних одиниць держсави
}

8. Neisser F., Runkel S. The future is now! Extrapolated riskscapes, anticipatory action and the management of potential emergencies. Geoforum. 2017, Vol. 82. P. 170-179.

doi: https://doi.org/10.1016/j.geoforum.2017.04.008.

9. System approach for readiness assessment units of civil defense to actions at emergency situations / V. V. Tiutiunyk et al. Sclentific Bulletin of National Mining University. 2018. Issue 1. P. 99-105. doi:https// doi:org/ 10.29202/nvngu/2018-1/7.

10. Биченок М. М., Трофимчук О. М. Проблеми природно-техногенної безпеки в Україні. Київ: РНБОУ, 2002. $153 \mathrm{c}$.

11. Акимов В. А., Новиков В. Д., Радаев Н. Н. Природные и техногенные чрезвычайные ситуации: опасности, угрозы, риски. Москва: Деловой экспресс, 2001. 304 с.

12. Комплексная оценка уровня риска опасного объекта / В. Д. Кондратьев и др. Системы управления и информационных технологий. 2004. № 3(15). С. 53 - 57.

13. Оцінка обстановки у надзвичайних ситуаціях / В. Є. Гончарук та ін. Львів: Нац. ун-т “Львів політехніка", 2004. 183 с.

14. Комплексні показники оцінювання стану природно-техногенної небезпеки адміністративнотериторіальних одиниць України / В. А. Андронов та ін. Проблеми надзвичайних ситуацій. Харків: Нац. ун-т цивільного захисту України, 2010. Вип. 12. С. 9 - 20.

15. Тютюник В. В. Оцінка відносної інтенсивності меж надзвичайних ситуацій природного та техногенного характеру в регіонах України. Проблеми надзвичайних ситуацій. Харків: Нац. ун-т цивільного захисту України, 2015. Вип. 21. С. 112 - 120.

16. Иванец Григорий, Горелышев Станислав. Оценка уровня техногенно-природно-социальной опасности регионов государства на основе метода векторно-статистического анализа с учетом площади их территории и количества населения. Власть и общество (История, Теория, Практика). Тбилиси, Грузия: Асоциация открытой дипломатии, 2016. № 3(39). С. 162-174.

Стаття надійшла до редакиії 09.09.2019 p.

\section{УДК 614.8}

\author{
Г. В. Иванец, С. А. Горелышев, М. Г. Иванец
}

\section{СТАТИСТИЧЕСКИЙ МЕТОД ОЦЕНИВАНИЯ УГРОЗ ТЕРРИТОРИЯМ И НАСЕЛЕНИЮ АДМИНИСТРАТИВНО-ТЕРРИТОРИАЛЬНЫХ ЕДИНИЦ ГОСУДАРСТВА}

В статье на основе среднестатистического ежегодного количества чрезвычайных ситуачий разработан статистический метод оценивания состояния угроз территориям и населению административно-территориальных единии государства с учетом их площади и количества населения. Метод позволяет классифицировать административно-территориальные единищь (регионы) государства за соответствующими уровнями состояния угроз территории и населению региона: относительно оптимальный, относительно допустимый и относительно неприемлемый.

Ключ е в ы е сло в а: чрезвычайная ситуация, административно-территориальная единица, комплексный показатель, уровни состояния угроз. 


\title{
UDC 614.8
}

\author{
Ivanets H., Horielyshev S., Ivanets M.
}

\section{STATISTICAL METHOD FOR ASSESSING THE LEVEL OF THREATS TO THE TERRITORY AND POPULATION OF ADMINISTRATIVE TERRITORIAL UNITS OF THE STATE}

Ensuring safety in emergency situations requires the reliable functioning of the response system to emergency of a natural, man-made and social nature, correspondent to the levels and nature of the threats. An important aspect of this activity is the timely assessment and prediction of the state of threats to the territory and population of the regions of the state, since the civil protection forces are distributed within the boundaries of the administrative-territorial units (regions, districts, cities, etc.). Each administrativeterritorial unit has its own levels of natural, technological and social risks, which significantly affect the composition of forces and means for an adequate response to emergency situations of a different nature.

Based on the average annual number of emergency situations, the article developed a statistical method for assessing the state of threats to the territory and population of the administrative-territorial units of the state, taking into account the area of their territory and the number of people. The method allows you to classify the administrative-territorial units (regions) of the state according to the corresponding levels of threats to the territory and population of the region: relatively optimal, relatively acceptable and relatively unacceptable.

Based on the proposed method, a model has been developed for assessing the state of threats to the territory and population of the state. This model includes logical modules connected into a single whole and informationally interconnected by purpose: the base of factual data on emergency situations of natural, technogenic and social nature both in the state as a whole and in its regions, a module of assessing of an indicator of threats to the territory and population of regions of the state, a module for assessing the complex indicator, a module for assessing the relative coefficient of annual intensity, a module for classifying levels of state of threat.

As a result of experimental studies based on statistics on emergency situations in Ukraine, it was found that the highest level of threats was obtained for the Autonomous Republic of Crimea, Donetsk, Lugansk, Dnepropetrovsk and Lviv regions.

K e y w ord s: emergency situations, administrative-territorial units of the state, integrated indicator, level of threats.

Іванець Григорій Володимирович - кандидат технічних наук, доцент, доцент кафедри піротехнічної та спеціальної підготовки Національного університету цивільного захисту України.

http:// orcid.org/ 0000-0002-4906-5265

Горслишев Станіслав Анатолійович - кандидат технічних наук, доцент, старший науковий співробітник науково-дослідного центру службово-бойової діяльності НГУ Національної академії Національної гвардії України

https://orcid.org/0000-0003-1689-0901

Іванець Михайло Григорович - кандидат технічних наук, старший науковий співробітник наукового центру Повітряних Сил Харківського національного університету Повітряних Сил імені Івана Кожедуба.

http:// orcid.org/ 0000-0002-3106-7633 